\title{
ANALISIS FAKTOR-FAKTOR YANG MEMPENGARUHI LOYALITAS PELANGGAN DAN DAMPAKNYA TERHADAP KEUNGGULAN BERSAING (STUDI PADA BMT AMANAH UMMAH SUKOHARJO)
}

\author{
Meyta Pritandhari \\ Pendidikan Ekonomi FKIP Universitas Muhammadiyah Metro \\ Mevta.pratandhari@gmail.com
}

\begin{abstract}
Abstrak
Baitul Maal Wat Tamwil merupakan salah satu model lembaga keuangan syariah yang saat ini banyak muncul di Indonesia. BMT Amanah Ummah memiliki 9.142 anggota dan 45 $\%$ anggotanya tidak loyal kepada BMT. Penelitian ini bertujuan untuk mengetahui faktorfaktor yang mempengaruhi loyalitas pelanggan dan dampaknya terhadap keunggulan bersaing.

Penelitian ini menggunakan metode penelitian deskriptif dengan pendekatan analisis kualitatif dengan model analisis interaktif. Teknik sampling yang digunakan adalan insidental sampling untuk anggota BMT dan purposive sampling untuk pimpinan, manajer dan marketing. Teknik pengumpulan data yang digunakan yaitu wawancara, observasi dan dokumentasi.

Hasil penelitian ini menunjukkan bahwa dari beberapa faktor yang mempengaruhi loyalitas pelanggan yaitu reputasi merek, kepuasan angggota, kualitas pelayanan, kualitas pelayanan berpengaruh positif terhadap kepuasan anggota, dan kualitas pelayanan. Dari beberapa faktor tersebut faktor kualitas pelayanan yang paling dominan dalam mempengaruhi loyalitas anggota.Dampak loyalitas terhadap keunggulan bersaing dapat dilihat dari seberapa banyak anggota BMT yang tidak pindah ke lembaga keuangan lain. Semakin bagus kualitas pelayanan maka semakin tinggi tingkat loyalitas dan keunggulan bersaing antar lembaga keuangan juga semakin tinggi.

Kata kunci: Baitul Maal Wat Tamwil (BMT), Loyalitas Pelanggan, Keunggulan Bersaing

PENDAHULUAN

Lembaga Keuangan merupakan bisnis jasa yang sudah banyak berkembang di Indonesia. Di Indonesia ada beberapa lembaga keuangan diantaranya yaitu: Bank, Koperasi, BMT. BMT adalah salah satu lembaga keuangan yang sederhana, namun cukup banyak menarik minat masyarakatnya untuk bergabung.

Kehadiran BMT muncul disaat umat Islam mengharapkan adanya lembaga keuangan berbasis syariah dan bebas dari unsur riba yang dinyatakan haram. Eksistensi lembaga keuangan syariah sejenis BMT, jelas memiliki arti penting bagi pembangunan ekonomi berwawasan syariah terutama dalam memberikan solusi bagi pembangunan ekonomi bagi pemberdayaan usaha kecil dan menengah
\end{abstract}


serta menjadi inti kekuatan ekonomi yang berbasis kerakyatan dan sekaligus menjadi penyangga utama sistem perekonomian nasional.

Bisnis jasa yang dilakukan oleh BMT yang harus diutamakan adalah kualitas pelayanan. Kualitas pelayanan menjadi faktor yang sangat penting menentukan keberhasilan bisnis ini. Kualitas layanan merupakan suatu bentuk penilaian konsumen terhadap tingkat layanan yang dipersepsi (perceived service) dengan tingkat pelayanan yang diharapkan (Expected service). Kualitas layanan dihasilkan oleh operasi yang dilakukan perusahaan, dan keberhasilan oleh proses operasi perusahaan ini ditentukan oleh banyak faktor, antara lain faktor karyawan, sistem teknologi dan keterlibatan nasabah atau anggota.

Semakin banyaknya lembaga keuangan syariah, persaingan antar lembaga keuangan sangat kompetitif. Lembaga Keuangan baik konvensional maupun syariah harus meningkatkan kualitas pelayanannnya. Dengan kualitas yang terus terjaga serta kenyamanan dan variasi produk yang ditawarkan diharapkan terus menarik minat anggota BMT. Hal ini juga dialami oleh posisi BMT Amanah Ummah sebagai salah satu lembaga keuangan syariah harus mampu bersaing secara kompetitif. Selain meningkatkan kualitas pelayanan BMT Amanah Ummah menawarkan berbagai macam alternatif produk kepada anggota misalnya simpanan ataupun pembiayaan yang mampu untuk bersaing. Dengan banyaknya pesaing, namun BMT Amanah ummah terus berkembang setiap tahunnya, jumlah anggota terus bertambah sehingga BMT Amanah Ummah menjadi BMT yang terus berkembang.

Loyalitas pelanggan merupakan salah satu faktor penting yang diupayakan dalam pemasaran modern. Loyalitas sangat penting karena diharapkan perusahaan akan mendapatkan keuntungan jangka panjang atas hubungan mutualisme yang terjalin dalam kurun waktu tertentu.

Kesetiaan konsumen (loyalitas) terhadap suatu barang atau jasa merek tertentu tergantung pada beberapa faktor diantaranya adalah besarnya biaya untuk berpindah ke merek barang atau jasa yang lain, adanya kesamaan mutu, kualitas atau pelayanan dari jenis barang atau jasa pengganti, adanya resiko perubahan biaya akibat barang atau jasa pengganti dan berubahnya tingkat kepuasan yang didapat dari merek baru dibanding dengan pengalaman terhadap merek sebelumnya yang pernah dipakai. Konsumen dalam memenuhi kebutuhan dan keinginannya, akan membeli produk dengan merek tertentu. Apabila merek yang dipilih konsumen itu dapat memuaskan kebutuhan dan keinginannya, maka konsumen akan memiliki suatu ingatan yang dalam 
terhadap merek tersebut. dalam keadaan semacam ini kesetiaan konsumen akan mulai timbul dan berkembang. Dalam pembelian yang berikutnya, konsumen tersebut akan memilih produk dengan merek yang telah memberinya kepuasan, sehingga akan terjadi pembelian yang berulang-ulang terhadap merek tersebut.

Perkembangan BMT Amanah Ummah ternyata mempunyai berbagai masalah yaitu salah satunya adalah tingkat loyalitas anggota yang masih rendah. Banyaknya anggota tidak berarti seluruh anggota yang terdaftar menjadi anggota yang aktif. Dari hasil studi pendahuluan yang telah dilakukan diketahui bahwa dari data seluruh anggota yang terdaftar ternyata tidak seluruhnya selalu aktif berinteraksi dengan BMT. Berikut disajikan tabel jumlah anggota Amanah Ummah sebagai berikut:

\begin{tabular}{|l|l|l|}
\hline Tahun & $\begin{array}{l}\text { Jumlah } \\
\text { Anggota }\end{array}$ & $\begin{array}{l}\text { \% anggota } \\
\text { yang loyal }\end{array}$ \\
\hline 2010 & 7.033 & $25 \%$ \\
\hline 2011 & 7.737 & $30 \%$ \\
\hline 2012 & 9.142 & $45 \%$ \\
\hline
\end{tabular}

Sumber: BMT Amanah Ummah

\section{KAJIAN PUSTAKA}

\section{Loyalitas}

Konsep loyalitas pelanggan berlaku untuk merek, jasa, organisasi, kategori produk dan aktivitas. Secara garis besar, literatur loyalitas pelanggan didominasi dua aliran utama : aliran skolastik (behavioral) dan aliran deterministik (sikap). Dengan kata lain, loyalitas merek dapat ditinjau dari merek apa yang dibeli konsumen dan bagaimana perasaan atau sikap konsumen terhadap merek tertentu.

Menurut Kotler (2008:18) "customer loyalty adalah suatu pembelian ulang yang dilakukan oleh seorang pelanggan karena komitmen pada suatu merek atau perusahaan".
Menurut Tjiptono

(2008:131) mengemukakan bahwa "loyalitas pelanggan sebagai komitmen pelanggan terhadap suatu merek, toko, pemasok berdasarkan sikap yang sangat positif dan tercermin dalam pembelian ulang yang konsisten” .

Ada beberapa indikator dalam mengukur loyalitas nasabah yaitu rebuy, retention dan referral (Rusdarti:2004). Sedangkan menurut Singh (dalam Rusdarti:2004) indikator loyalitas konsumen adalah prosentase dari pembelian, frekuensi kunjungan dan merekomendasikan kepada orang lain.

Menurut Dick \& Basu (dalam Tjiptono 2011:137) dengan meng- kombinasikan komponen sikap dan perilaku pembelian ulang, maka didapatkan 4 situasi 
kemungkinan loyalitas yaitu sebagai berikut:

a) No Loyalty

Bila sikap dan perilaku pembelian ulang pelanggan sama-sama lemah, maka loyalitas tidak terbentuk.

b) Spurious Loyalty

Bila sikap negatif lemah dibarengi dengan pola pembelian ulang yang kuat, maka yang terjadi adalah spurious loyalty atau captive loyalty

c) Latent Loyalty

Situasi latent loyalty tercermin bila sikap yang kuat dibarengi dengan pola pembelian ulang yang lemah

d) Loyalty.

Situasi ini merupakan situasi ideal yang paling diharapkan para pemasar, dimana konsumen bersikap positif terhadap jasa atau penyedia jasa bersangkutan dan disertai pola pembelian ulang yang konsisten.

\begin{tabular}{|c|c|}
\hline \multicolumn{1}{|c}{ Kuat } & Kuat \\
\hline Loyalty & $\begin{array}{c}\text { Latent } \\
\text { Loyalty }\end{array}$ \\
\hline Loyalty & Noyalty \\
\hline Lemah & Lemah \\
\hline
\end{tabular}

Gambar 2.1 Perilaku Pembelian Ulang (Tjiptono, 2011)

\section{Reputasi Merek}

$$
\text { Menurut }
$$

Aaker

(dalam

Ferdinand:2003) reputasi merek dapat didefinisikan sebagai persepsi tentang kualitas yang berhubungan dengan nama perusahaan.Merek memegang peran penting ketika tanda atau atribut intrinsik menjadi sulit atau tidak mungkin untuk ditampilkan. Termasuk dalam tanda intrinsik adalah wujud fisik atau komposisi teknis dari sebuah produk.

Merek (brand name) dikaitkan dengan tanda ekstrensik yaitu atribut yang melekat pada sebuah produk tetapi tidak memerlukan pemahaman secara detail dan spesifik dari karakteristik produk tersebut.

Beberapa indikator yang digunakan untuk mengukur variabel reputasi merek diacu dari penelitian Selnes (dalam Smith and Wright: 2004). Adapun indikatorindikator tersebut adalah nama baik, reputasi dibanding pesaing, dikenal luas dan kemudahan diingat. Nama baik adalah persepsi dari nasabah tentang bagaimana nama baik yang berhasil dibangun oleh bank. Reputasi dibanding pesaing adalah persepsi nasabah bank mengenai seberapa baik reputasi bank tersebut jika dibandingkan bank- bank lain.

\section{Kepuasan Pelanggan}

Pada mulanya konsep kepuasan dapat didefinisikan sebagai kepuasaan yang terjadi setelah pertimbangan evaluasi pilihan yang memperhatikan pada keputusan pembeliaan Churchill dan Sauprenant, (dalam Smith and Wright: 
2004). Menurut Kotler (2008: 254) kepuasan adalah perasaan kesenangan atau kekecewaan dari hasil membandingkan performa produk yang diterima dalam hubungannya dengan perkiraannya. Sedangkan Yi (dalam Smith and Wright:2004) berpendapat kepuasaan pelanggan adalah output dari persepsi, evaluasi dan reaksi psikologis dalam pengalaman konsumsi pada sebuah produk atau pelayanan.

Menurut Ho dan Wu (dalam Saha dan Zhao:2005) ada 5 hal yang membentuk kepuasan pelanggan logistical support, technical characteristics, information characteristics, home page presentation dan product characteristhics. Beberapa indikator yang digunakan untuk mengukur variabel kepuasan pelanggan ini diacu dari penelitian Selnes (dalam Saha dan Zhao:2005) adalah rasa senang, kepuasan terhadap pelayanan, kepuasan terhadap sistem dan kepuasan finansial. Rasa senang menunjukkan sejauh mana para nasabah merasa senang dengan pengalaman transaksinya selama berhubungan dengan bank tersebut.Kepuasan pelanggan menunjukkan sejauh mana para nasabah merasa puas dengan cara dan sikap para karyawan bank dalam melayani transaksinya.

\section{Kualitas Pelayanan}

Persaingan antar bank yang semakin ketat, maka baik bank swasta maupun bank pemerintah bersaing untuk memikat agar para nasabahnya tetap loyal dalam memanfaatkan pelayanan yang diberikannya. Salah satu aspek yang perlu mendapatkan perhatian penting adalah kualitas pelayanan yang diberikan oleh bank. Kualitas pelayanan berpusat pada upaya pemenuhan kebutuhan dan keinginan serta ketepatan penyampaiannya untuk mengimbangi harapan pelanggan.

Menurut Rusdati (2004) Ada dua faktor yang mempengaruhi kualitas jasa yaitu expected service dan perceived service. Kualitas harus dimulai dari kebutuhan pelanggan dan berakhir pada persepsi pelanggan. Hal ini berarti citra kualitas yang baik bukanlah berdasarkan sudut pandang atau persepsi penyedia jasa melainkan berdasarkan sudut pandang atau persepsi pelanggan. Baik buruknya kualitas pelayanan jasa menjadi tanggung jawab seluruh bagian organisasi perusahaan. Total Quality Control merupakan syarat utama dalam bersaing dan bertahan. Total Quality Control (TQC) menjadi tanggung jawab semua orang dalam organisasi dalam rangka menciptakan kualitas pelayanan, sehingga pada akhirnya konsumen akan memeperoleh tawaran pelayanan dengan kualitas yang tinggi. Pada hakikatnya TQC merupakan bagian dari visi strategi manajemen kualitas. 
Menurut Parasuraman (dalam Saha dan Zhao:2005) mengidentifikasi faktor penentu dari kualitas pelayanan yaitu tangibles, reliability, responsiveness, communication, access, competence, courtesy, credibility, security, understanding/ knowledge of customer. Kemudian 10 dimensi ini dikembangkan dan disederhanakan menjadi tangibles, reliability, responsiveness, assurance dan empathy untuk mengukur kualitas pelayanan (SERVQUAL). Menurut Parasuraman (dalam Saha dan Zhao:2005) (1) Tangible yaitu fasilitas fisik yang ditawarkan kepada konsumen dan materi komunikasi; (2) emphathy yaitu kesediaan untuk peduli, memberikan perhatian pribadi kepada pelanggan, kemudahan untuk melakukan hubungan dan pemantauaan terhadap keinginan konsumen; (3) responsiveness, yaitu kemauan untuk membantu pelanggan dan memberikan jasa dengan cepat; (4) reliability, yaitu konsistensi dari penampilan pelayanan dan keandalan pelayanan dan (5) assurance yaitu kemampuan, ketrampilan, keramahan, kepercayaan dan keamanan dari para petugas.

\section{Keunggulan Bersaing}

Menurut Porter (dalam Ferdinand, 2003). Setiap perusahaan berusaha untuk mengidentifikasikan, menciptakan sebuah keunggulan bersaing. Porter (dalam Ferdinand : 2003) mendukung konsep keunggulan bersaing tapi mengharuskan keunggulan bersaing tidak hanya selesai dengan melakukan improvisasi perusahaan yang efektif dan bahwa kenyataannya keunggulan bersaing didapatkan untuk menjadi berbeda tidak menjadi lebih baik.

Menurut Tjiptono (2011: 201), cara lain untuk melakukan diferensiasi kualitas pelayanan terhadap keunggulan bersaing adalah secara konsisten memberikan kualitas pelayanan yang lebih baik daripada para pesaing. Hal ini dapat dicapai dengan memenuhi atau bahkan melampaui kualitas jasa yang diharapkan para pelanggan. Kualitas jasa sendiri dipengaruhi oleh dua variabel, yaitu jasa yang dirasakan (perceived service) dan jasa yang diharapkan (expexted service). Bila jasa yang dirasakan lebih kecil daripada yang diharapkan, maka para pelanggan menjadi tidak tertarik lagi pada penyedia jasa yang bersangkutan. Bila yang terjadi adalah sebaliknya (perceived > expexted), maka ada kemungkinan para pelanggan akan menggunakan penyedia jasa itu lagi.

Menurut Porter (dalam Ferdinand : 2003) keunggulan bersaing tumbuh secara mendasar dengan mengeluarkan nilai lebih dari perusahaan sehingga perusahaan mampu menciptakan pembeli/konsumen yang lebih banyak dengan biaya yang dikeluarkan sesuai 
kemampuan perusahaan.

Menurut Porter (dalam

Ferdinand:2003) ada 2 tipe dasar dari keunggulan bersaing yaitu low cost atau differentiation. Perusahaan dengan mengikuti salah satu strategi ini dan berusaha untuk menjaga atau mengembangkan tentunya akan memperoleh posisi dalam pasar. Perusahaan seharusnya mencari strategi yang paling bagus dalam untuk mengeksploitasi karakteristik perusahaan dan keunikannya.

\section{METODE PENELITIAN}

Penelitian ini dilakukan di Baitul Maal Wat Tamwil (BMT) Amanah Ummah Sukoharjo.Penelitian ini menggunakan metode penelitian deskriptif dengan pendekatan analisis kualitatif, yaitu mendeskripsikan data yang ter- kumpul ke dalam kalimat-kalimat yang memiliki arti lebih mendalam, karena menggambarkan secara tepat individu, keadaan, gejala, atau kelompok tertentu, guna menentukan frekuensi adanya hubungan antara satu gejala dengan gejala lainnya.

Ditinjau dari apek yang diteliti, penelitian ini merupakan study kasus (case study). Studi kasus adalah bentuk penelitian yang mendalam tentang suatu aspek lingkungan sosial termasuk manusia di dalamnya.Sumber data merupakan sumber dimana data dapat diperoleh.
Pengumpulan data dalam penelitian kualitatif dilakukan pada natural setting (kondisi yang alami), sumber data primer, dan teknik pengumpulan data lebih banyak pada observasi terus terang atau tersamar, wawancara mendalam (in depth interview) dan dokumentasi. Sumber data yang digunakan dalam penelitian ini adalah:

a) Data primer, yaitu data yang diperoleh langsung melalui wawancara kepada:

1) Manajer Marketing dari BMT yang merupakan seorang yang aktif dalam bidang pemasaran.

2) Para anggota BMT yang merupakan anggota tetap dari BMT.

3) Para pengurus BMT yang terlibat langsung dalam kegiatan pemasaran BMTL

b) Data sekunder, yaitu data yang diperoleh secara tidak langsung melalui arsip,data dan dokumen yang memiliki hubungan erat dengan permasalahan kajian penelitian.

\section{Teknik sampling}

Menurut Sugiyono (2013:297) Istilah populasi dalam penelitian kualitatif dinamakan social situation atau situasi sosial yang terdiri dari tiga elemen yaitu: tempat (place), pelaku (actors), dan aktivitas (activity) yang berinteraksi secara sinergis. Dalam penelitian kualitatif tidak menggunakan populasi, karena penelitian kualitatif berangkat dari kasus tertentu 
yang ada pada situasi sosial tertentu dan hasil kajiannya tidak akan diberlakukan ke populasi, tetapi ditransferkan ke tempat lain pada situasi sosial yang memiliki kesamaan dengan situasi sosial pada kasus yang dipelajari Sugiyono (2013:295). Teknik sampling yang digunakan dalam penelitian ini sebagai berikut:

\section{Sampling Insidental}

Penelitian ini menggunakan sampling insidental yaitu teknik penentuan sampel berdasarkan kebetulan, yaitu siapa saja yang secara kebetulan insidental bertemu dengan peneliti dapat digunakan sebagai sampel, bila dipandang orang yang kebetulan ditemui itu cocok sebagai sumber data Sugiyono (2013:295). Dalam penelitian ini menggunaka sampling insidental untuk mencari data anggota. Karena mewawancarai anggota tidak bisa ditentukan secara pasti, jadi anggota yang kebetulan datang ke BMT akan dijadikan sebagai sampel.

\section{Purposive Sampling}

Purposive sampling adalah teknik pengambilan sampel sumber data dengan pertimbangan tertentu. Pertimbangan ini, misalnya orang tersebut yang dianggap paling tahu tentang apa yang kita harapkan, atau dia sebagai penguasa sehingga akan memudahkan peneliti menjelajahi obyek/situasi sosial yang diteliti Sugiyono (2013:300).

Pada penelitian ini purposive sampling digunakan untuk mencari data strategi pemasaran yang digunakan BMT, jadi yang paling mengerti tentang strategi pemasaran adalah pimpinan, manajer marketing dan anggota marketing.

Teknik pengumpulan data adalah wawancara, observasi dan dokumentasi. Data yang dikumpulkan melalui wawancara adalah tentang:

a) Strategi pemasaran yang digunakan untuk menarik minat anggota BMT.

b) Kendala yang dihadapi oleh marketing BMT dalam memasarkan produk BMT kepada anggota

c) Upaya-upaya yang dilakukan BMT dalam meningkatkan loyalitas anggota Teknik pemeriksaan data dalam penelitian ini menggunakan metode triangulasi sumber dan triangulasi metode. Hal ini dilakukan dengan membandingkan hasil dari pengamatan, wawancara, dan analisis dokumen. Diharapkan hasil akhir dari analisis mencapai tingkat mutu dan kevalidan yang tinggi.

Teknik analisis data yang digunakan dalam penelitian ini menggunakan pola penelitian induktif yang diolah dengan teknik saling terjalin atau interaktif mengalir. Teknik data dalam penelitian ini mengikuti model analisis interaktif (Interactive Model of Analysis). Aktivitas dalam analisis data, yaitu reduksi data, penyajian data dan penarikan kesimpulan atau verifikasi. 
PEMBAHASAN HASIL PENELITIAN

BMT Amanah Ummah setiap tahun memiliki peningkatan jumlah anggota. Berdasarkan grafik yang telah disajikan dapat diketahui bahwa terjadi peningkatan anggota dari tahun 2010 sampai tahun 2011 sebanyak 704 anggota. Dari tahun 2011 sampai tahun 2012 mengalami kenaikan yang cukup signifikan yaitu 1.405 anggota Dari data jumlah anggota tahun 2012 sebanyak 9.142 orang adalah data anggota seluruhnya yang terdaftar pada BMT Amanah Ummah.

Keberadaan anggota adalah merupakan aset berharga yang perlu mendapatkan perhatian yang lebih. Memiliki jumlah anggota yang terus meningkat tentu harus diperlukan konsep pelayanan yang baik. BMT dituntut untuk memenuhi kebutuhan anggota akan kecepatan pelayanan. Dengan memiliki kualitas pelayanan yang baik maka anggota akan merasa puas sehingga mereka tidak berpaling pada BMT ataupun lembaga lain.

Loyalitas pelanggan berawal dari penilaian pelanggan terhadap kualitas produk atau jasa yang diterimanya (persepsi) berdasarkan harapan yang telah terkonsep dalam pikirannya. Harapan tersebut muncul dari produk atau jasa yang telah diterima sebelumnya (pengalaman) serta berita dari mulut ke mulut yang sampai pada pelanggan. Penilaian tersebut akan menimbulkan kepuasan dan ketidakpuasan. Pelanggan akan merasa puas jika kualitas yang diberikan telah sesuai atau bahkan melebihi harapan pelanggan. Namun sebaliknya jika kualitas produk atau jasa yang diberikan kurang atau berada di bawah harapan, maka pelanggan akan kecewa. Anggota BMT sudah puas dengan produk dan pelayanan yang telah diberikan oleh BMT. Namun, ternyata dengan kepuasan saja tidak cukup membuat anggota BMT loyal. Anggota BMT yang sudah puas masih tidak loyal dengan BMT. Hal ini dikarenakan faktor internal dan eksternal orang yang berbeda-beda sehingga walaupun sudah puas jika anggota tidak mempunyai kebutuhan dan pendapatan yang lebih maka anggota tidak memakai produk BMT lagi.

Jika dilihat dari loyalitas BMT Amanah Ummah tahun 2012 sebanyak 45\% anggota yang loyal termasuk dalam situasi spurious loyalty yaitu bila sikap negatif lemah dibarengi dengan pola pembelian ulang yang kuat. Sikap negatif yang dimaksud adalah persepsi kepercayaan anggota terhadap BMT yang baru bagi anggota. Jadi anggota BMT belum mengenal BMT tapi ingin mencoba produk BMT sehingga anggota BMT termasuk spurious loyalty. Jika dibandingkan dengan loyalitas tahun 2012 yang termasuk kategori spurious loyalty, maka hasil wawancara yang telah dilakukan meningkat ke kategori latent loyalty yaitu mulai ada sikap positif dari 
anggota terhadap BMT karena menggunakan strategi personal selling yang dapat menciptakan hubungan positif dengan anggota. Hal ini terbukti dari loyalitas anggota yang meningkat dikarenakan marketing BMT menjalin hubungan yang baik denga anggota sehingga anggota merasa aman dan nyaman bekerjasama dengan BMT. Anggota yang loyal biasanya memakai produk BMT lebih dari satu produk atau dapat juga memakai produk BMT yang sama secara konsisten.

Perusahaan yang memiliki keunggulan kompetitif senantiasa memiliki kemampuan dalam memahami perubahan struktur pasar dan mampu memilih strategi pemasaran yang efektif.

Memiliki keunggulan bersaing artinya kita memiliki keunggulan baik satu atau beberapa bidang sehingga kita mampu memenangkan persaingan. ada beberapa pandangan mengenai keunggulan bersaing. satu dari pandangan tersebut yang saya yakini cukup komprehensif adalah ada 3 area dimana kita dapat menggali keunggulan bersaing kita yaitu kualitas dan keunikan produk, biaya, dan bagaimana kita merespon kebutuhan pelanggan.

a) Kualitas dan keunikan produk.

Suatu perusahaan dapat unggul terhadap kompetitornya kalau memiliki produk (barang dan jasa) yang berkualitas. selama perusahaan dapat menyediakan kualitas produk yang melebihi kompetitornya maka perusahaan ini dikatakan memiliki keunggulan bersaing. jika ternyata dalam hal kualitas perusahaan sudah disamai oleh banyak kompetitornya, maka memberikan sesuatu yang berbeda juga dapat mengantarkan perusahaan menjadi pemimpin dalam bisnis. secara singkat, strategi pertama ini memfokuskan diri untuk menjadi lebih baik, atau paling tidak berbeda dengan kompetitor.

b) Biaya.

Perkembangan teknologi memungkinkan orang untuk berpindah kurva bisnis, dimana penurunan biaya juga dapat diraih sambil meningkatkan respon kepada pelanggan ataupun meningkatkan kualitas produk. Teknologi internet telah mengubah cara berbisnis dengan sangat signifikan. dengan pasar yang menjadi tidak terbatas, kecepatan komunikasi dengan pelanggan dan pemasok, kantor yang menjadi virtual dengan karyawan minimum, itu semua memungkinkan kita beroperasi dengan lebih murah.

c) Respon.

Ada 2 hal yang perlu diperhatikan. pertama adalah kecepatan merespon, yang kedua adalah variasi produk yang kita tawarkan kepada pelanggan. semakin cepat kita merespon 
kebutuhan pelanggan, atau semakin banyak solusi yang kita tawarkan kepada pelanggan akan membawa kita memenangkan persaingan. maka dalam strategi ini kita akan fokus untuk menjadi lebih cepat atau lebih fleksibel.

\section{KESIMPULAN}

Berdasarkan hasil penelitian yang telah dipaparkan maka dapat ditarik kesimpulan:

a) Faktor-faktor yang dapat mempengaruhi loyalitas diantaranya yaitu: kualitas pelayanan, reputasi merk, dan kepuasan pelanggan.

b) Diantara berbagai faktor yang mempengaruhi loyalitas, faktor kualitas layanan adalah yang paling mendominasi anggota untuk loyal terhadap BMT.

c) Keunggulan bersaing antar lembaga keuangan sangat kompetitif dan sangat positif untuk kemajuan semua lembaga keuangan.

Untuk meningkatkan loyalitas anggota dapat dilakukan dengan berbagai cara diantaranya sebagai berikut:

a) Loyalitas adalah faktor penting dalam sebuah bisnis. Oleh karena itu tingkatkan loyalitas dari anggota dengan pelayanan yang berkualitas. b) Keunggulan bersaing yang diciptakan oleh BMT, Bank, Koperasi dan lembaga keuangan lainnya harus bersaing secara kompetitif dan sehat.

\section{DAFTAR PUSTAKA}

Ferdinand, Augusty. 2003. Suistainable Competitive Adventage. Bad Penerbit Universitas Diponegoro: Semarang.

Kotler, P \& Gary Amstrong. 2008. DasarDasar Pemasaran Jilid 2. Jakarta: Erlangga.

Rusdarti. 2004. "Pengaruh Kualitas Pelayanan Dan Nilai Pelayanan Terhadap Loyalitas Nasabah Pada Bank BPD Jawa Tengah Cabang Semarang”. Jurnal Bisnis Strategi,Vol. 13, Juli,pp 54-65.

Saha, Parmita dan Zhao, Yanni. 2005. "Relationship Between Online Service Quality And Customer Satisfaction A study in Internet Banking". Master'Thesis :083

Smith, Rodney E, and Wright, William F. 2004. "Determinants of Customer Loyalty and Financial Performance" Journal of Management Accounting Research. Vol.16 pg. 183

Sugiyono. 2013. Metode Penelitian Pendidikan Pendekatan Kuantitatif, Kualitatif, dan $R \& D$. Bandung: Alfabeta.

Tjiptono, F. dkk. (2008). Pemasaran Jasa. Yogjakarta: Andi.

(2011). Pemasaran Jasa. Yogjakarta: Andi. 